\title{
The threshold value of a quality index for formation of cellular manufacturing systems
}

\author{
H. SEIFODDINI $\dagger$ and M. DJASSEMI+
}

\begin{abstract}
The superiority of cellular manufacturing to job shop manufacturing has been questioned by a number of simulation studies. The initial structure of the machinepart matrix seems to play an important role in the failure of cellular manufacturing systems in these studies. In this paper a grouping measure called "quality index--. QI' will be used to evaluate the relationship between the quality of a machine-part matrix and the performance of the corresponding cellular manufacturing system. A simulation stucly will be conducted to demonstrate how the procedure can be used to determine the threshold value for QI beyond which the cellular manufacturing system outperforms the corresponding job shop manufacturing system.
\end{abstract}

\section{Introduction}

Manufacturing is undergoing one of its most profound changes since the introduction of mass production. Globalization has created a competitive environment in which only the most efficient corporations survive. As a response to this challenge manufacturers alli. over the world are using the most innovative manufacturing techniques available. One such technique is cellular manufacturing (CM) which overcomes the inefficiencies of traditional batch-type manufacturing through reduction in setup times, in-process inventories, and throughput times. In CM the bencfits of economy of scale is achieved by grouping similar parts into part-families and processing them into dedicated machine cells (Burbidge 1975, Hyer 1984). Ideally a part-family is processed in a single machine cell for its entire operations. In practice, however, some parts (exceptional parts) have operations on machines (bottleneck machines) outside their parent cell (King 1980).

Data for formation of machine cells and part-families is organized in the machinepart (M-P) matrix which is a binary matrix with zero one entries. A 'one' entry in row $i$ and column $j$ of the matrix indicates that part $j$ has an operation(s) on machine $i$ while a zero entry indicates it does not. The machine cell formation algorithms convert the M-P matrix into a block diagonal form in which 'one' entries are concentrated in blocks along the diagonal of the matrix. Each block represent a machine-component group in the corresponding CM system (Seifoddini and Wolf 1986). The initial structure of a M-P matrix to a great extent determines the performance of the corresponding $\mathrm{CM}$ system.

As an attempt to evaluate the goodness of a M-P matrix, a number of grouping measures such as bond energy (McCormick, et al. 1972), grouping efficiency (Chandrasekharan and Rajagopalan 1989), grouping efficacy (Kumar and Chandrasekharan 1990) and grouping capability index (Hsu 1990) have been developed. Most

\footnotetext{
Industrial and Manufacturing Engineering Department, University of Wisconsin, Milwaukec, USA.

†Industrial Studies Department, University of Wisconsin. Platteville, USA.
} 
of these measures are based on the relative number of 'one' entries inside and outside the diagonal blocks. Grouping efficiency tends to have a high value for complete block diagonal matrices in which all 'one' entries are inside the blocks.

While successful cases of CM are well documented (Wemmerlov and Hyer 1989) and (Hyer 1984), several simulation studies show that conversion from job shop to $\mathrm{CM}$ may result in inferior performance in some manufacturing systems. Contributing factors to performance deterioration include long queues in front of bottlencek machines, under utilization of non-bottleneck machines, and infexibility of dedicated machine cells in dealing with changes in product mix (Ang and Willey 1984, Flynn and Jacobs 1986).

A study by authors indicates that there are some common characteristics in failed $\mathrm{CM}$ cases including dense M-P matrices. Therefore, the identification of such characteristics and establishment of their relations to the pcrformance of the corresponding $\mathrm{CM}$ systems are two crucial steps toward more successful development of such systems.

In this paper a grouping measure called 'quality index-QI' is used to evaluate $\mathrm{M}-\mathrm{P}$ matrices. Then simulation modelling will be employed to measure the performance of the corresponding CM system by estimating the average flow times, in-process inventories, and so on. Finally, a number of different $\mathbf{M}-\mathbf{P}$ matrices are used to determine the relationship between different values of QI and the performance of the corresponding $\mathrm{CM}$ system. The purpose is to determine the threshold value of the QI beyond which $\mathrm{CM}$ system will outperform the corresponding job shop manufacturing system.

\section{Definition of the problem}

The benefits of CM has been questioned by a number of simulation studies including Christy and Udayan (1986), Flynn and Jacobs (1986), Sarper (1988), Garza (1990), Sassani (1990), and Shafer and Meredith (1990). These studies indicate that the formation of dedicated machine cells generally reduces the availability of machines for the processing of parts in the product mix. This leads to high inventory accumulation in front of bottleneck machines, low utilization of non-bottleneck machines and imbalanced workload distribution among machine cells. Cellular manufacturing is also less flexible in dealing with changes in the product mix.

Some of the above mentioned problems including the imbalanced workload distribution can be overcome by using alternative routeing (Burbidge 1992), outsourcing (Burbidge 1975), machine duplication (Seifoddini, 1989) and the formation of hybrid machine cells (Seifoddini 1992). Some other problems, such as the inflexibility of dedicated machine cells in the case of changing product mix, merit careful analysis prior to any decision regarding the development of a CM system. Yet other problems, such as excessive intercellular moves and inefficient shopfloor operations, may be signs of illsuited situations for conversion to cellular manufacturing. Therefore each manufacturing situation should be carefully evaluated before conversion to $\mathrm{CM}$.

In a simulation study by Flynn and Jacobs (1986), the conversion from job shop manufacturing to $\mathrm{CM}$ led to longer queues, higher work-in-process inventories, and longer waiting lines. In this study the characteristics of the manufacturing system including its dense M-P matrix (Shafer and Meredith 1990) might have been the main reason for the poor performance of the corresponding $\mathrm{CM}$ system. Generally, the structure of the M-P matrix has a great impact on the performance of the corresponding $\mathrm{CM}$ system. Therefore, the evaluation of the block diagonal M-P matrix provides 
useful information on its suitability for the development of a CM system. The three important components of such an evaluation include a grouping measure, performance measures, and a simulation model.

Among the existing grouping measures, quality index (QI) is the most effective one (Seifoddini and Djassemi 1994). QI is the measure of independence of machine component groups. Since independent machine cells are ideal for the formation of $\mathrm{CM}$ systems, a high value of $\mathrm{QI}$ is expected to lead to a high performance level in the corresponding $\mathrm{CM}$ system.

QI can be defined as,

$$
\mathrm{QI}=1-\frac{\mathrm{ICW}}{\mathrm{PW}}
$$

where,

$$
\begin{aligned}
\text { ICW } & =\text { Total intercellular workload } \\
\text { PW } & =\text { Total plant workload }
\end{aligned}
$$

ICW, on the other hand, can be defined as

$$
\mathrm{ICW}=\sum_{\mathrm{C}=1}^{\mathrm{C}} \sum_{\mathrm{M}=1}^{\mathrm{M}}\left[\mathrm{Y}_{\mathrm{mc}}\left(\sum_{\mathrm{P}=1}^{\mathrm{P}}\left(1-\mathrm{Z}_{\mathrm{pc}}\right) \mathrm{X}_{\mathrm{mp}} \mathrm{V}_{\mathrm{p}} \mathrm{T}_{\mathrm{mp}}\right)\right]
$$

where,

$$
\begin{aligned}
\mathrm{Y}_{\mathrm{mc}} & = \begin{cases}1, & \text { if machine } m \text { is assigned to cell } c \\
0, & \text { otherwise }\end{cases} \\
Z_{\mathrm{pc}} & = \begin{cases}1, & \text { if part } p \text { is assigned to cell } c \\
0, & \text { otherwise }\end{cases} \\
\mathrm{X}_{\mathrm{mp}} & = \begin{cases}1, & \text { if part } p \text { has operation on machine } m \\
0, & \text { otherwise }\end{cases} \\
\mathrm{V}_{\mathrm{p}} & =\text { volume of part } p \\
\mathrm{~T}_{\mathrm{mp}} & =\text { processing time of part } p \text { on machine } m \\
\mathrm{M} & =\text { total number of machines } \\
\mathrm{P} & =\text { total number of parts } \\
\mathrm{C} & =\text { total number of cells }
\end{aligned}
$$

PW can be defined as,

$$
\mathrm{PW}=\sum_{\mathrm{n}=1}^{\mathrm{M}} \sum_{\mathrm{p}=1}^{\mathrm{P}} \mathrm{X}_{\mathrm{mp}} \cdot \mathrm{V}_{\mathrm{p}} \cdot \mathrm{T}_{\mathrm{np}}
$$

$\mathrm{X}_{\mathrm{mp}}, \mathrm{V}_{\mathrm{p}}$ and $\mathrm{T}_{\mathrm{mp}}$ as defined before.

For performance evaluation, measures such as mean flow time, mean work-inprocess inventories, mean set-up time, mean number of intercellular moves, and mean operator productivity are widely used in the literature and will be employed here (Djassemi 1994).

In order to compare the performance of a manufacturing systcm under job shop 
and CM configuration, a simulation model is used. In the simulation analysis, the performance of the manufacturing systems with different M-P matrices will be evaluated by using one of the above mentioned performance measures. Then the relationship between values of QI and the performance of the corresponding manufacturing system will be determined using statistical analysis. Finally, threshold value of QI beyond which the CM system outperforms its corresponding job shop manufacturing system is determined.

\section{Comparison of job shop and cellular manufacturing}

The comparison of manufacturing systems under job shop and $\mathrm{CM}$ configurations is done in three phases. In the first phase the M-P matrix is converted into a block diagonal form which is used to develop a CM system. The value of QI for the block diagonal form is also calculated at this phase. In the second phase, a simulation model of both job shop and CM system is constructed. This simulation model is used to estimate different performance measures for the two systems based on a number of different M-P matrices and their corresponding QI values. Finally, statistical analysis is used to test the significance of the differences between the performances of the two systems at different QI levels.

The algorithmic form of the procedure can be summarized as follows:

(1) Convert the M-P matrix into a block diagonal form using one of the existing machine-component grouping algorithms such as ROC (King 1980) or SCM (Seifoddini and Wolf 1986).

(2) Calculate the value of QI for the block diagonal form.

(3) Use simulation to estimate the performance measures for both job shop and $\mathrm{CM}$ systems under a specific manufacturing situation.

(4) Determine the statistical significance of the difference between the performances of the two systems.

(5) Repeat steps 1 to 4 for a set of different M-P matrices and QI's. The value of Ql can be changed,

(a) by redistribution of entries of the M-P matrix or

(b) by changing the density of the M-P matrix.

(6) Determine the value of QI beyond which CM system outperforms its corresponding job shop manufacturing system.

Since a number of different performance measures have been employed in this study, it is expected that a range of QI values is determined as a threshold value for converting a job shop system to a cellular manufacturing system.

The procedure presented here is based on the following assumptions.

(1) An efficient machine-component grouping algorithm is used to form machine cells for CM.

(2) Raw materials are ready at the beginning of the shift.

(3) Machine breakdowns are not considered (this can be a serious problem if the effects of machine breakdowns is significantly different in CM and job shop).

(4) There is one operator for every two machines and job rotation occurs in machine cells.

This is a comparative study and hence it does not scem that these assumptions impose any serious limitation on the viability of results. Assumption 4, however, requires more exploration and can be the subject of a new study. 
Since simulation is a major part of this procedure a brief discussion of important features of the simulation model will be presented in the following section.

\subsection{Simulation modelling}

SIMAN/CINEMA IV simulation language is used for model translation (Pegden et al. 1990). SIMAN provides a flexible modelling environment for manufacturing systems including built in features for modclling of work stations, transportations, wating lines, and so on. CINEMA animation is also helpful, especially for model verification (Djassemi 1994).

Continuity and degeneracy tests (removing some machines and checking for performance deterioration) were conducted for model validation. Common random numbers were used for minimizing variations. The replication/deletion graphical method (Law and Kelton 1991) was used to minimize the effects of the transient period and the results for 100 days of simulation ( 50000 time units) were discarded. Finally, batching method was used for parameter estimation (Law and Kelton 1991). Data for the steady state period were divided into 20 batches of size 13 days.

\subsection{Input data}

The main input to the simulation model include;

(1) A M-P matrix which provides the information for the development of job shop and CM systems.

(2) Routing and operational data including processing times and base setup times.

(3) Product mix and arrival patterns.

M-P matrices for two manufacturing situations used in this paper are given in Figs 1 and 7. Additional M-P matrices for different QI values are given in appendix A of Djassemi (1994). The interarrival times for parts in the M-P matrices in Figures 1 and 7 are exponentially distributed with mean interarrival time of 10 minutes and 60 minutes, respectively. Data on the processing times of parts and their routeings are given in appendix A of Djassemi (1994). In addition, it is assumed that the general time coefficient (GTC) for different sequencing possibilities is as follows:

(1) For two identical parts loaded sequentially, GTC $=0 \cdot 1$,

(2) For two parts from the same part-family loaded sequentially, GTC -0.5 ,

(3) For two parts from different part-families loaded sequentially, GTC =- 1 .

GTC is multiplied by the base setup time to generate sctup times for different sequencing scenarios.

\subsection{Statistical analysis}

The difference between the mean performances of the two systems is used as the basis for their comparison. To determine the statistical significance of the difference, the paired- $t$ test is employed. The following are provided.

- The difference between mean performance measures,

- Paired- $t$ confidence interval for the mean differences,

- T'est of hypothesis concerning the two means.

The following hypothesis is tested:

Ho: No difference exists between the performances of a job shop manufacturing 
PARTS

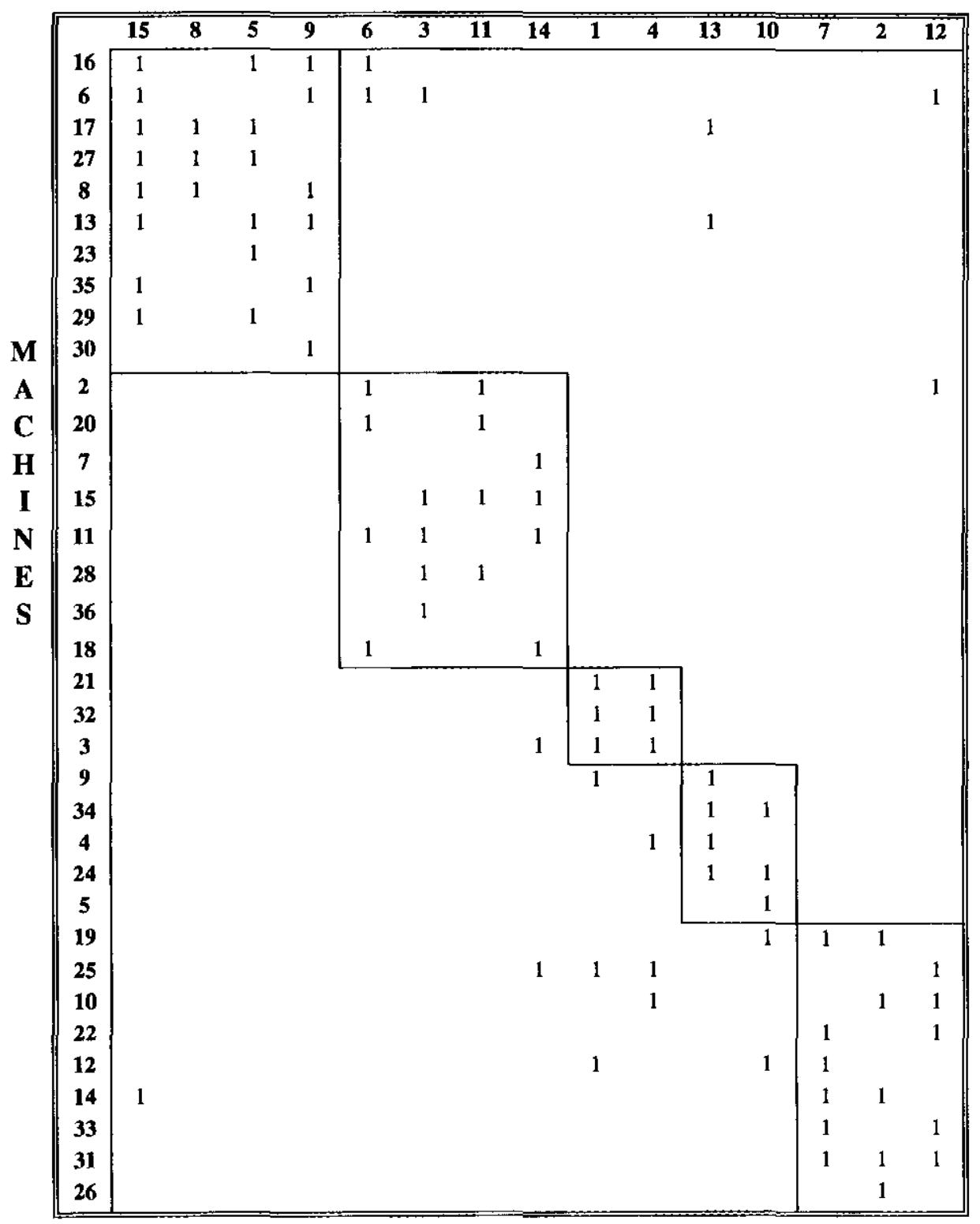

Figure 1. Machine-part matrix $(\mathrm{QI}=0 \cdot 78)$.

system and the corresponding cellular manufacturing system at a specific QI value.

The rejection of $H o$ implies that one of the two systems is superior for the given QI values. To deal with the individual performance measures of a job-shop manufacturing system and the corresponding CM system, the above hypothesis should be modified as follows:

$H_{o_{1}}$ : There is no difference between the mean flow times of the two systems. 
$\mathrm{Ho}_{2}$ : There is no difference between the mean work-in-process (WIP) inventories of the two systems.

$\mathrm{Ho}_{3}$ : There is no difference betwcen the mean setup times of the two systems.

$\mathrm{Ho}_{4}$ : There is no difference between the mean number of intercellular (interdepartmental) moves in the two systems.

$\mathrm{Ho}_{5}$ : There is no difference between the mean operator productivity in the two systems.

Rejection of any of these hypothesis is an indication of the superiority of one of the two systems with respect to the corresponding performance measure.

\section{Analysis of results}

In this section simulation results and the results of test of hypothesis for a number of different QI values are summarized. A brief discussion about each value of QI is provided.

The data on the product mix, machining requirements of parts, and machines are organized in the M-P matrix in Fig. 1. Other production data such as routings, the distribution of interarrival times, batch sizes of orders, base setup times, and modified. versions of M-P matrix for different values of QI are in Djassemi (1994).

The QI value for the initial M-P matrix (Fig. 1) is 0.78 . A QI value of 0.86 can be obtained by a $10 \%$ reduction in the density of the matrix. Another $10 \%$ reduction in the density of the matrix generates a QI value of 0.91 . If all exceptional parts are eliminated from the matrix, a QI value of 1 is achieved. On the other hand, a $20 \%$ increase in the density of the matrix generates a QI value of 0.68 .

The simulation results for the M-P matrix with the QI of 0.68 is given in Table 1 . The results for the test of hypothesis (at $\alpha=0.05$ ) are summarized in Table 2. At this QI level, the mean flow time and WIP are significantly higher in CM system. As expected the mean setup time and number of part movements are lower in the $\mathrm{CM}$ system. This leads to higher operator productivity for the CM system.

\begin{tabular}{llllll}
\hline $\begin{array}{l}\text { Shop } \\
\text { type }\end{array}$ & $\begin{array}{c}\text { Flow time } \\
\text { (hours) }\end{array}$ & WIP (parts) & $\begin{array}{c}\text { Setup } \\
\text { time }(\%)\end{array}$ & $\begin{array}{c}\text { Number of } \\
\text { intercell moves }\end{array}$ & Operator \\
\hline Job shop & $128^{*}$ & $3 \cdot 02$ & $19 \cdot 9$ & $21 \cdot 13$ & $3 \cdot 17$ \\
& $125-129^{* *}$ & $2 \cdot 98 \cdot 3 \cdot 12$ & $19 \cdot 5 \cdot-20 \cdot 2$ & $20 \cdot 2-21 \cdot 18$ & $3 \cdot 15-3 \cdot 20$ \\
CM shop & 154 & $4 \cdot 71$ & $5 \cdot 4$ & $6 \cdot 05$ & $3 \cdot 4$ \\
& $152-157$ & $4 \cdot 53-4 \cdot 84$ & $5 \cdot 3-5 \cdot 52$ & $5 \cdot 95 \cdot 6 \cdot 13$ & $3 \cdot 32--3 \cdot 51$ \\
\hline
\end{tabular}

*Mean $* * 95 \%$ Confidence interval

Table 1. Simulation results for $\mathrm{QI}=0.68$.

\begin{tabular}{lcc}
\hline Performance measure & $\begin{array}{c}\text { Mean differences of two } \\
\text { models and } 95 \% \text { C.I. }\end{array}$ & Test of hypothesis \\
\hline Mean flow time & $26 \pm 2.4$ & Reject $\mathrm{H}_{\mathrm{oB} 1}$ \\
Mean WIP & 1.67 .0 .86 & Reject $\mathrm{H}_{\mathrm{oB} 2}$ \\
Mean sctup time & $0.145 \pm 0.006$ & Reject $\mathrm{H}_{\mathrm{OB} 3}$ \\
Mcan \# of intercell moves & $15 \pm 0.92$ & Reject $\mathrm{H}_{\mathrm{oB} 4}$ \\
Operator productivity & $0.22 \pm 0.11$ & Reject $\mathrm{H}_{\mathrm{oB} 5}$ \\
\hline
\end{tabular}

Table 2. Results of test of hypothesis for $\mathrm{QI}=0 \cdot 68$. 


\begin{tabular}{cllccc}
\hline Shop type & $\begin{array}{c}\text { Flow time } \\
\text { (hours) }\end{array}$ & WIP (parts) & $\begin{array}{c}\text { Setup time } \\
(\%)\end{array}$ & $\begin{array}{c}\text { Number of } \\
\text { intercell moves }\end{array}$ & Operator \\
\cline { 1 - 5 } Job shop & $105^{*}$ & $2 \cdot 68$ & 20 & $19 \cdot 86$ & $3 \cdot 07$ \\
& $101-108^{* *}$ & $2 \cdot 45-2 \cdot 79$ & $19 \cdot 5-2 \cdot 79$ & $18 \cdot 8-20 \cdot 3$ & $7 \cdot 98 \cdot-3 \cdot 12$ \\
CM shop & 112 & $3 \cdot 52$ & $5 \cdot 1$ & $3 \cdot 17$ & $3 \cdot 48$ \\
& 109.116 & $3 \cdot 45-3 \cdot 62$ & $5 \cdot 0 \cdot 5 \cdot 16$ & $3 \cdot 143 \cdot 20$ & $3 \cdot 35-3 \cdot 58$ \\
\hline
\end{tabular}

*Mean **95\% Confidence interval

Table 3. Simulation results for $\mathrm{QI}=0 \cdot 78$.

\begin{tabular}{lcc}
\hline & $\begin{array}{c}\text { Mean differences of two } \\
\text { models and 95\% C.I. }\end{array}$ & Test of hypothesis \\
\hline Mean flow timc & $7.0+4.2$ & Reject $\mathrm{H}_{\mathrm{OB} 1}$ \\
Mean WIP & $0.80 \pm 0.09$ & Reject $\mathrm{H}_{\mathrm{OB} 2}$ \\
Mean sctup time & $0.145 \pm 0.03$ & Reject $\mathrm{H}_{\mathrm{OB} 3}$ \\
Mean \# of intercell moves & $16.5 \pm 1.14$ & Reject $\mathrm{H}_{\mathrm{OB} 4}$ \\
Operator productivity & $0.40 \pm 0.02$ & Reject $\mathrm{H}_{\mathrm{OB} S}$ \\
\hline
\end{tabular}

Table 4. Results of test of hypothesis for QI $=0.78$.

\begin{tabular}{|c|c|c|c|c|c|}
\hline Shop type & $\begin{array}{l}\text { Flow time } \\
\text { (hours) }\end{array}$ & WIP (parts) & $\begin{array}{c}\text { Setup time } \\
(\%)\end{array}$ & $\begin{array}{l}\text { Number of } \\
\text { intercell moves }\end{array}$ & Operator \\
\hline \multirow[t]{2}{*}{ Job shop } & $97 \cdot 16^{*}$ & $3 \cdot 04$ & 20 & $19 \cdot 79$ & $3 \cdot 51$ \\
\hline & $96 \cdot 1-98 \cdot 2^{* *}$ & $2 \cdot 99 \cdot 3 \cdot 14$ & $19 \cdot 2 \quad 20 \cdot 3$ & $19 \cdot 2-20 \cdot 01$ & $3 \cdot 46 \cdot 3 \cdot 62$ \\
\hline \multirow[t]{2}{*}{ CM shop } & 96.8 & $3 \cdot 48$ & $4 \cdot 4$ & $2 \cdot 57$ & $4 \cdot 05$ \\
\hline & $96 \cdot 2 \cdots 97 \cdot 3$ & $3 \cdot 41-3 \cdot 53$ & $4 \cdot 1-4 \cdot 6$ & $2 \cdot 45 \cdot-2 \cdot 66$ & $3 \cdot 97-4 \cdot 13$ \\
\hline
\end{tabular}

${ }^{*}$ Mean $* * 95 \%$ Confidence interval

Table 5. Simulation results for QI -0.86 .

\begin{tabular}{lcc}
\hline Performance measure & $\begin{array}{c}\text { Mean differences of wo } \\
\text { models and } 95 \% \text { C.I. }\end{array}$ & Test of hypothesis \\
Mean flow time & $0.35 \pm 0.52$ & Accept $\mathrm{H}_{\mathrm{oB} 1}$ \\
Mean WIP & $0.45 \pm 0.09$ & Reject $\mathrm{H}_{\mathrm{oB} 2}$ \\
Mean sctup time & $0.132 \pm 0.08$ & Reject $\mathrm{H}_{\mathrm{oB} 3}$ \\
Mean \# of intercell moves & $17.2 \pm 0.1$ & Reject $\mathrm{H}_{\mathrm{OB} 4}$ \\
Operator productivity & $0.51 \pm 0.016$ & Reject $\mathrm{H}_{\mathrm{OB} 5}$ \\
\hline
\end{tabular}

Table 6. Results of test of hypothesis for $\mathrm{QI}=0 \cdot 86$.

When the original M-P matrix $(\mathrm{QI}=0.78)$ is used, the simulation results and the summary of results for the test of hypothesis are given in Tables 3 and 4 . At this QI level, the mean flow time and WIP are still higher in the CM system. It seems that a higher level of QI is needed to improve these two performance measures in the CM system.

If the density of the M-P matrix is reduced by $10 \%(\mathrm{QI}=0.86)$, the simulation results improve as shown in Table 5. At this QI level the difference between the two systems in terms of mean flow time is not statistically significant. Based on the WIP level, however, still the job shop system outperforms the CM system. The results for the test of hypothesis are presented in Table 6. 


\begin{tabular}{|c|c|c|c|c|c|}
\hline Shop, type & $\begin{array}{l}\text { Flow time } \\
\text { (hours) }\end{array}$ & $W \| P$ (parts) & $\begin{array}{l}\text { Setup time } \\
(1 \%)\end{array}$ & $\begin{array}{l}\text { Number of } \\
\text { intercell moves }\end{array}$ & Operator \\
\hline \multirow[t]{2}{*}{ Job shop } & $89 \cdot 19^{*}$ & $2 \cdot 74$ & 20 & $18 \cdot 9$ & $3 \cdot 2$ \\
\hline & $86 \cdot 8-91 \cdot 2^{* *}$ & $2 \cdot 69-2 \cdot 82$ & $19 \cdot 8-20 \cdot 2$ & $18 \cdot 2-19 \cdot 01$ & $3 \cdot 09-3 \cdot 22$ \\
\hline \multirow[t]{2}{*}{ CM shop } & $85 \cdot 78$ & $3 \cdot 18$ & $4 \cdot 1$ & 1.69 & 3.67 \\
\hline & $84 \cdot 1-86 \cdot 2$ & $3 \cdot 11--3 \cdot 21$ & $4 \cdot 01 \quad 4 \cdot 14$ & $1.56 \quad 1.72$ & $3 \cdot 58 \cdot 3 \cdot 71$ \\
\hline
\end{tabular}

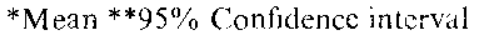

Table 7. Simulations results for $\mathrm{QI}=0.91$.

\begin{tabular}{|c|c|c|}
\hline Performance measure & $\begin{array}{c}\text { Mean differences of two } \\
\text { models and } 95 \% \text { C.I. }\end{array}$ & Test of hypothesis \\
\hline Mcan flow time & $3 \cdot 2 \pm 0 \cdot 9$ & Reject $H H_{o B I}$ \\
\hline Mean WIP & $0 \cdot 24+0 \cdot 03$ & Reject $H_{\mathrm{OB} 2}$ \\
\hline Mean setup time & $0.125 \perp .0 \cdot 003$ & Reject $\mathrm{H}_{\mathrm{OB} 3}$ \\
\hline Mean \# of iniercel! moves & $17.2 \pm 0.52$ & Reject $H_{\circ B 4}$ \\
\hline Operator productivity & $0 \cdot 48+0 \cdot 02$ & Reject $\mathrm{H}_{\mathrm{OB} 5}$ \\
\hline
\end{tabular}

Table 8. Results of test of hypothesis for $Q \mathrm{I}=0-91$.

\begin{tabular}{|c|c|c|c|c|c|}
\hline Sliop type & $\begin{array}{l}\text { How time } \\
\text { (hours) }\end{array}$ & WIP (parts) & $\underset{(\%)}{\text { Selup time }}$ & $\begin{array}{l}\text { Number of } \\
\text { interceil moves }\end{array}$ & Operator \\
\hline Job shop & $82^{*}$ & 2.96 & $18 \cdot 8$ & $18 \cdot 84$ & $3 \cdot 48$ \\
\hline & $81 \cdot 282 \cdot 6^{* *}$ & $2 \cdot 55 \cdot 3 \cdot 02$ & $18 \cdot 2-19 \cdot 02$ & $18.83 \quad 18.86$ & $3 \cdot 45-3 \cdot 51$ \\
\hline \multirow[t]{2}{*}{ CM shop } & $66 \cdot 3$ & $2 \cdot 13$ & 3.9 & 0 & $3 \cdot 94$ \\
\hline & $65 \cdot 8-66 \cdot 9$ & $2 \cdot 09-2 \cdot 15$ & $\begin{array}{lll}3 \cdot 7 & 4 \cdot 2\end{array}$ & & $3 \cdot 88-3 \cdot 96$ \\
\hline
\end{tabular}

*Mean **95\% Confidence interval

Table 9. Sinulation results for QI ... 1 .

\begin{tabular}{lcc}
\hline & $\begin{array}{c}\text { Mean differences in two } \\
\text { models and } 95 \% \mathrm{C.J}\end{array}$ & Test of hypothesis \\
Performance measure & $15.6 \pm 0.52$ &...- \\
Mean flow time & $0.82 \pm 0.08$ & Reject $\mathrm{H}_{\mathrm{OB} 1}$ \\
Mean WIP & $0.145 \pm 0.04$ & Reject $\mathrm{H}_{\mathrm{OB} 2}$ \\
Mean setup time & $18.84 \pm 0$ & Reject $\mathrm{H}_{\mathrm{OB} 3}$ \\
Mean H of intercell moves & $0.46 \pm 0.05$ & Reject $\mathrm{H}_{\mathrm{OB} 34}$ \\
Operator productivity & Reject $\mathrm{H}_{\mathrm{OB} 5}$ \\
\hline
\end{tabular}

Table 10. Results of test of hypothesis for QI $=1$.

In the next trial the M-P matrix is further improved by another $10 \%$ reductions in its density $(\mathrm{QI}=0.91)$. The simulation results for this QI are given in Table 7 and the results of test of hypothesis are presented in Table 8. At this Ql level the performance of CM system further improves and it outperforms the job shop system in all porformance measures except WIP.

Finally, when the M-P matrix is rearranged to achieve a $Q 1$ value of 1 , the simulation results indicate that CM system is outperforming the corresponding job shop system in all performance measures employed in this study. The simulation results and the results of test of hypothesis are given in Tables 9 and 10 . 


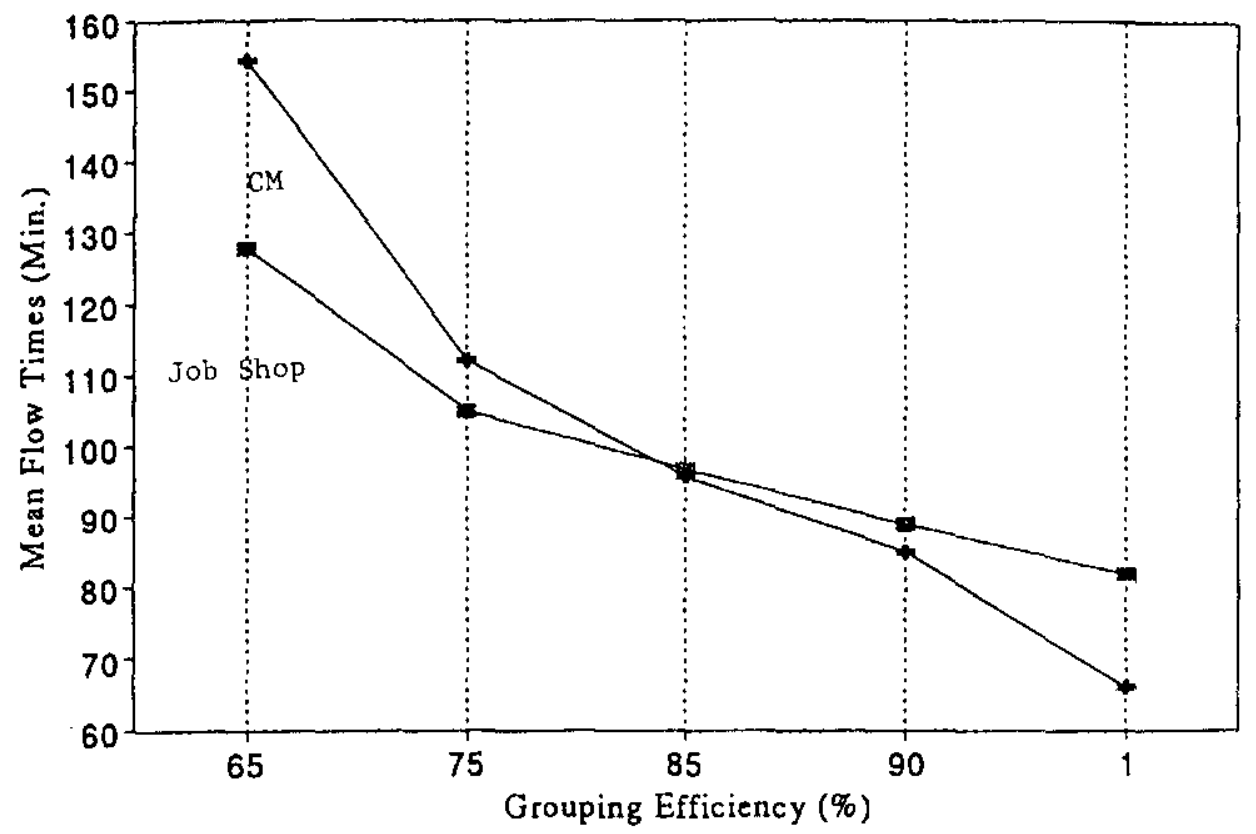

Figure 2. Comparison of mean flow times.

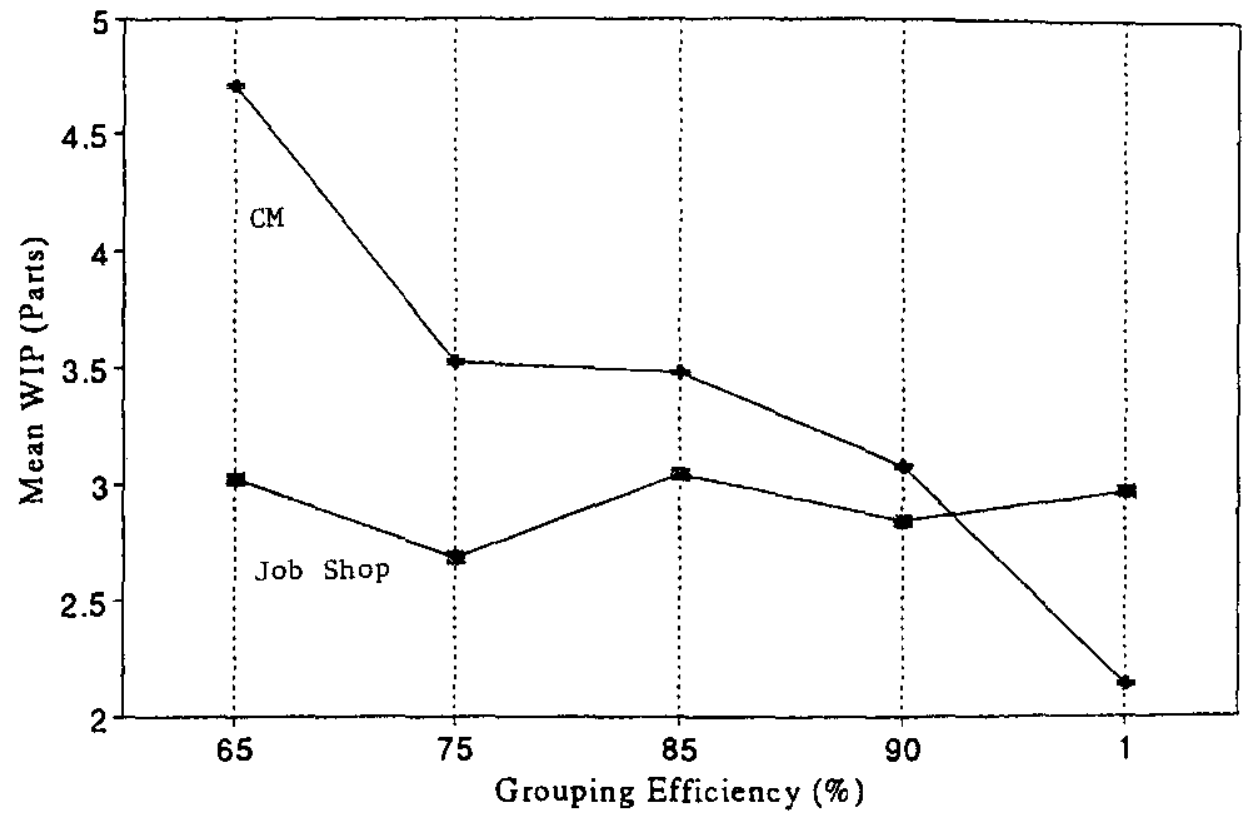

Figure 3. Comparison of WIP. 


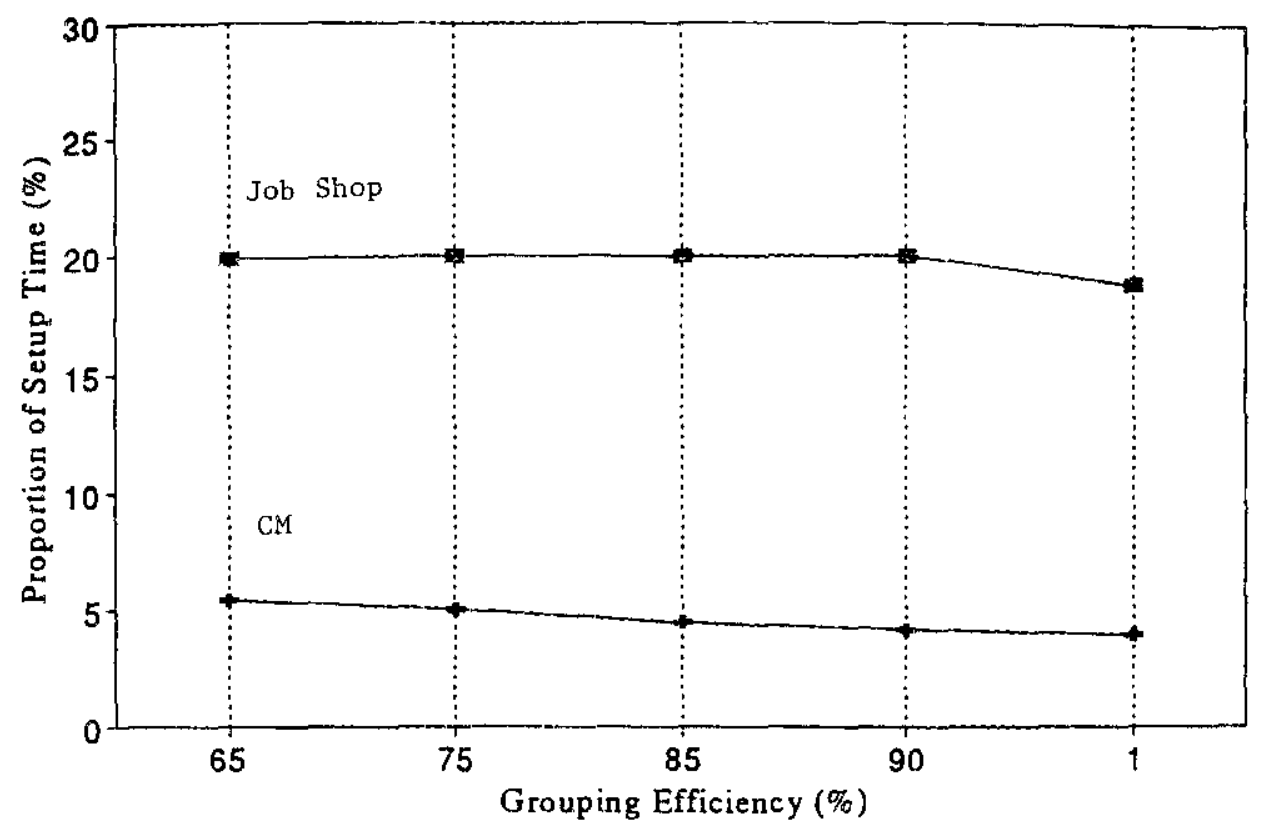

Figure 4. Comparison of proportion of setup time.

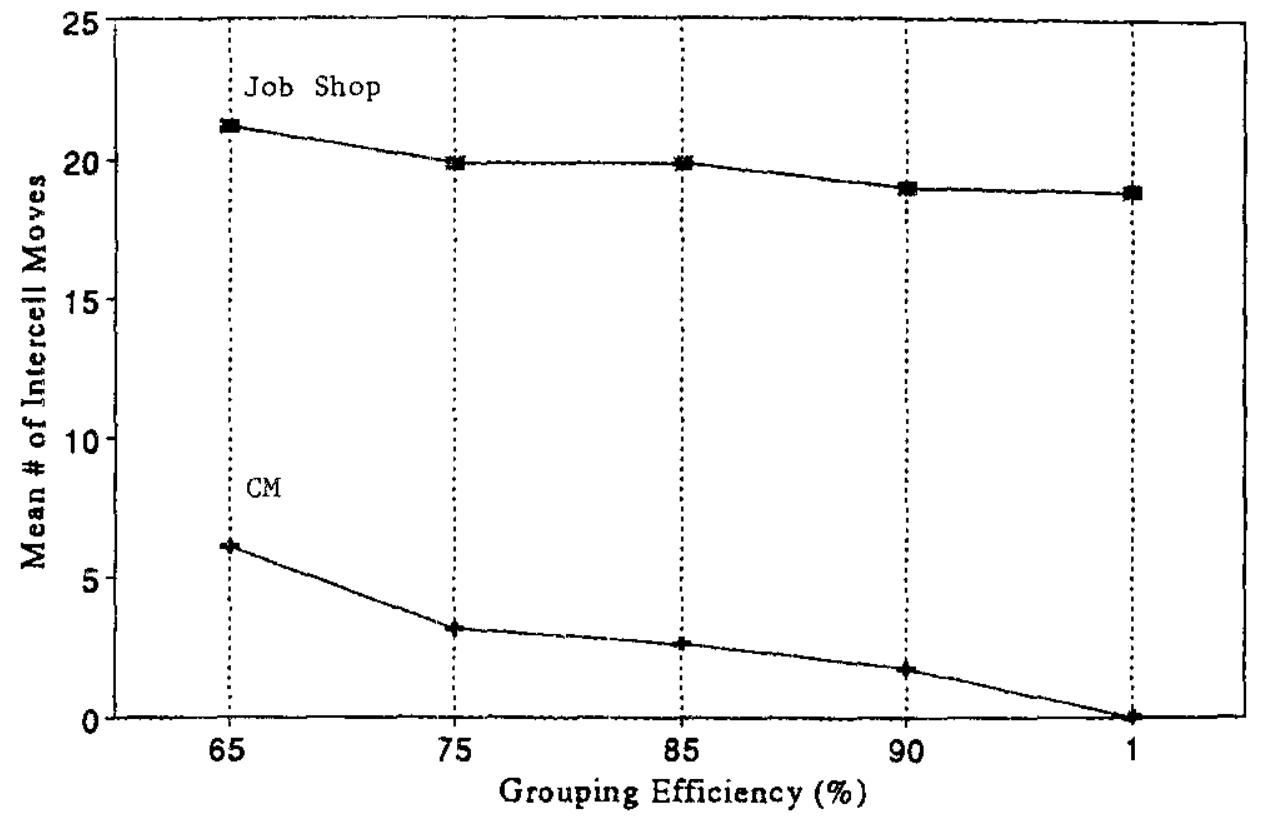

Figure 5. Comparison of mean of intercell moves. 


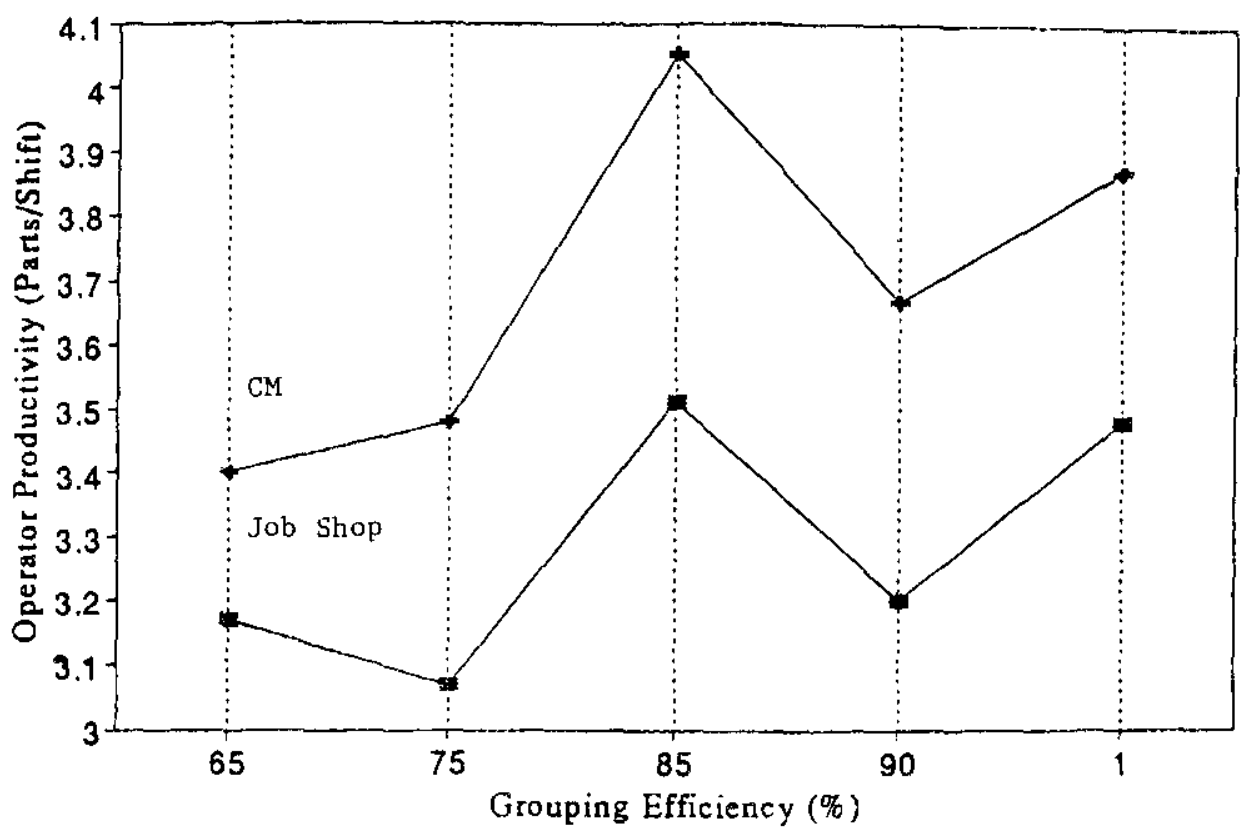

Figure 6. Comparison of mean productivity.

Performance measure

Mean flow time

Mean WIP

Mcan setup time

Mcan \# of intercell moves

Mean productivity
Mean differences of two models and $95 \%$ C.I.

$$
\begin{gathered}
44 \cdot 2 \pm 3 \cdot 6 \\
5 \cdot 951.0 \cdot 65 \\
16 \% \pm 1 \cdot 8 \\
27 \cdot 7 \pm 0 \\
3 \cdot 2 \pm 0.25
\end{gathered}
$$

Test of hypothesis

Reject $H_{o / 31}$

Reject $\mathrm{H}_{\mathrm{OB} 2}$

\begin{tabular}{|c|c|c|c|c|c|}
\hline Shop type & $\begin{array}{l}\text { How time } \\
\text { (hours) }\end{array}$ & $\begin{array}{l}\text { WIP } \\
\text { parts }\end{array}$ & Setup iime & $\begin{array}{l}\text { Number of } \\
\text { intcrcell moves }\end{array}$ & $\begin{array}{c}\text { Operator } \\
\text { productivity } \\
\text { parts shift }\end{array}$ \\
\hline \multirow[t]{2}{*}{ Job shop } & $74 \cdot 6^{*}$ & $7 \cdot 47$ & $68 \cdot 6 \%$ & $25 \cdot 6$ & $2 \cdot 2$ \\
\hline & $71 \cdot 2 \quad 77 \cdot 1^{* * *}$ & $6 \cdot 8-8 \cdot 1$ & $58-76$ & $26 \cdot 1-25 \cdot 2$ & $2 \cdot 11-2 \cdot 29$ \\
\hline \multirow[t]{2}{*}{ CM shop } & 49 & $5 \cdot 61$ & $53 \%$ & $1 \cdot 48$ & $3 \cdot 85$ \\
\hline & $46 \cdot 9 \cdot 52 \cdot 1$ & $4 \cdot 5 \cdot 6 \cdot 4$ & $47-.58 \cdot 2$ & $0 \cdot 8-2 \cdot 1$ & $3.78 \cdots 3.91$ \\
\hline
\end{tabular}

Reject $\mathrm{H}_{\mathrm{OB} \text { ? }}$

Reject $\mathrm{H}_{\mathrm{ol34}}$

Reject. $\mathrm{H}_{\mathrm{oB} 4}$

Táble 11. Paired- 1 test results for Q5 $=1 \cdot 0$.

Table 12. Simulation results for $\mathrm{QI}=0 \cdot 90$.

Further insight into the comparison of the job shop and CM systems at different QI levels can be obtained by the graphical presentation of results as depicted in Figs 2-6.

The gradual improvement of performance measures in the $\mathrm{CM}$ system as the value of QI increases is a clear indication that QI can be used as an effective tool for the evaluation of an M-P matrix. The decision about conversion from job shop to cellular 
PAR'S

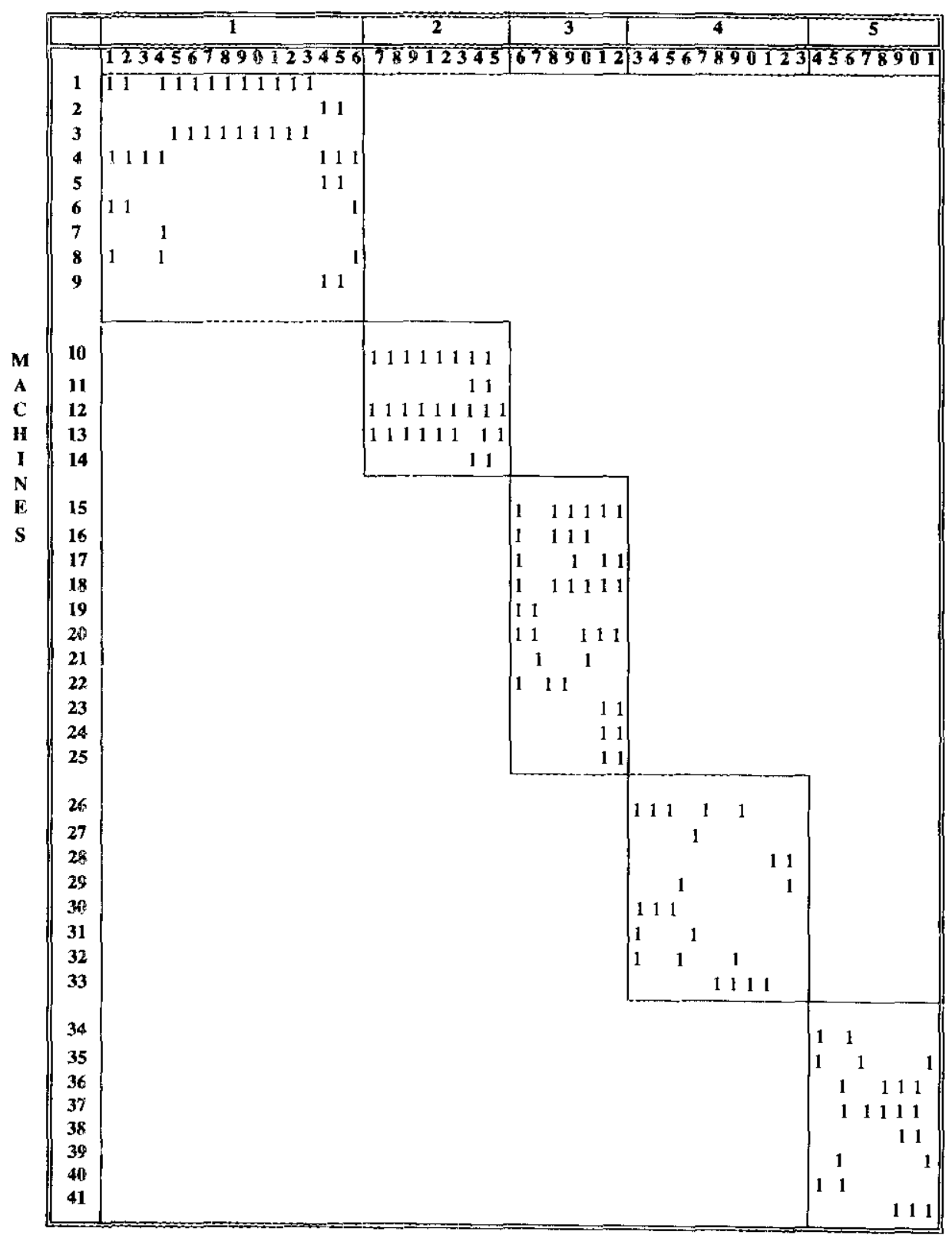

Figure 7. M-P matrix ol a real manufacturing system.

manufacturing, however, cannot be solely on the QI value. Generally for a very high value of $\mathrm{QI}$ (close to $100 \%$ ), conversion to $\mathrm{CM}$ is beneficial. When the value of QI is very low (close $1050 \%$ ), then it is not.

The procedure is now applied to a real world manufacturing system. The M-P matrix for this system is given in Fig. 7 and the other related production data are 


\begin{tabular}{|c|c|c|}
\hline Performance measure & $\begin{array}{l}\text { Mean differcnces of two } \\
\text { models and } 95 \% \text { C.I. }\end{array}$ & Test of hypothesis \\
\hline Mean flow time & $24 \cdot 2 \pm 5 \cdot 63$ & Reject $\mathrm{H}_{\mathrm{OBI}}$ \\
\hline Mean WIP & $1.75 \pm 0.08$ & Reject $\mathrm{H}_{\mathrm{OB} 2}$ \\
\hline Mean setup time & $15.6 \% \pm 0.09$ & Reject $\mathrm{H}_{O B 3}$ \\
\hline Mean \# of intercell moves & $24 \cdot 1 \pm 0 \cdot 06$ & Reject $\mathrm{H}_{\mathrm{OB} 4}$ \\
\hline Mean productivity & $1.66 \pm 0.011$ & Reject $\mathrm{H}_{\mathrm{OB} 5}$ \\
\hline
\end{tabular}

Table 13. Paircd- $t$ test results for $\mathrm{QI}=0 \cdot 90$.

\begin{tabular}{|c|c|c|c|c|c|}
\hline Shop type & $\begin{array}{l}\text { Flow time } \\
\text { (hours) }\end{array}$ & $\begin{array}{l}\text { WIP } \\
\text { parts }\end{array}$ & Setup time & $\begin{array}{c}\text { Number of } \\
\text { intercell moves }\end{array}$ & $\begin{array}{l}\text { Operator } \\
\text { productivity } \\
\text { parts/shift }\end{array}$ \\
\hline \multirow[t]{2}{*}{ Job shop } & $81^{*}$ & 8 & $68 \%$ & $27 \cdot 8$ & $2 \cdot 06$ \\
\hline & $80 \cdot 5-81 \cdot 5^{* *}$ & $7 \cdot 4-8 \cdot 7$ & $58-75 \cdot 2$ & $26 \cdot 5-28 \cdot 7$ & $1.99-2.09$ \\
\hline \multirow[t]{2}{*}{ CM shop } & $66 \cdot 9$ & 8.6 & $53 \%$ & $3 \cdot 45$ & $3 \cdot 65$ \\
\hline & $63 \cdot 8 \cdot 68 \cdot 6$ & $8 \cdot 3-8 \cdot 72$ & $47 \cdots 57.9$ & $2 \cdot 8 \cdot 4 \cdot 1$ & $3 \cdot 58-3.69$ \\
\hline
\end{tabular}

Table 14. Simulation results for $\mathrm{QI}=0 \cdot 85$.

\begin{tabular}{lcc}
\hline Mean differences of two & \\
Performance measure & $\begin{array}{c}\text { Medels and 95\% C.I. } \\
\text { Mean flow time }\end{array}$ & Test of hypothesis \\
Mean WIP & $0.5 \pm 0.04$ & Reject $\mathrm{H}_{\mathrm{OB} 1}$ \\
Mean setup time & $14.5 \% \pm 0.07$ & Acept $\mathrm{H}_{\mathrm{oB} 2}$ \\
Mean \# of intercell moves & $24 \cdot 2 \pm 1.2$ & Reject $\mathrm{H}_{\mathrm{OB} 3}$ \\
Mean productivity & $1.57 \pm 0.04$ & Reject $\mathrm{H}_{\mathrm{OB} 5}$ \\
\hline
\end{tabular}

Table 15. Paired- $t$ test results for $\mathrm{QI}=0.85$.

given in Djassemi (1994). The simulation and paired-l test results for this manufacturing situation further demonstrates the usefulness of the procedure.

At $\mathrm{QI}=1 \cdot 0$, the cellular manufacturing system outperforms the corresponding job shop system in all performance measures (Table 11). When QI drops to 0.90 , the simulation and paired-t test results are given in Tables 12 and 13. As the results indicate at this QI level the cellular manufacturing system still outperforms the corresponding job shop system in all performance measures. At QI $=0.85$, the cellular manufacturing system outperforms the job shop system in four out of five performance measures. The simulation results and results for the paired $t$-test are summarized in Tables 14 and 15. As QI drops further, the performance of cellular manufacturing systems deteriorates and it fails to outperform the job shop system in more and more performance measures.

A more comprehensive study of a range of manufacturing systems is required to determine a threshold value of QI for conversion to cellular manufacturing for a general manufacturing situation. Those two numerical examples, however, demonstrate how Ql in conjunction with simulation can be used to determine such a threshold value. 


\section{Conclusions}

The procedure presented in this paper can be used to determine the relationship between values of QI and the performance of the corresponding cellular manufacturing system. The simulation results showed that as the value of QI increases, the mean flow time and WIP inventories for the cellular manufacturing system decrease. For high values of QI (close to $100 \%$ ) the CM system outperformed the corresponding job shop system in all performance measures used in this study. On the other hand, at low values of QI (close to $50 \%$ ) the job shop outperforms the corresponding CM system. This study shows that QI serves as an effective tool in the cvaluation of the M-P matrix for conversion to C.M.

\section{References}

ANG, C. P. and WILIEY, P. C., 1984, A comparative study of the performance of pure and hybrid group technology manufacturing systems using computer simulation techniques. International Journal of Production Research, 22(2), 193 -233.

Burbiocil. J., 1992, Change to group technology: process organization is obsolete. International Journal of Production Research, 30(5), 1209-1220.

BURBIDGe, J., 1975, The Introduction of Group Technology (New York: Wiley).

Chandrasekharan, M. P. and Rajagopalan, R., 1989, Groupability: an analysis of the properties of binary data matrices for group technology, I1. International Journal of Production Research, 27(6), 1035-1052.

Christy, P. D. and Udayan, N., 1986, A simulation investigation of the design of group technology cells. II. Proceedings of the Annual Meeting of the Decision Sciences Institute, pp. $1201 \cdot 1203$.

Dıassfam, M., 1994, The use of machine-grouping efficiency in comparison of job shop and cellular manufacturing systems: a simulation study. PhD. thesis, Department of Industrial and Manufacturing Engincering, University of Wisconsin Milwaukee.

FLYNN, B. B. and JACOBS, F. R., 1986, A simulation comparison of group technology with traditional job shop manufacturing. International Journal of Production Research, 24(5), $1171-1192$

GAR\%A, O., 1990. The effect of intercell flow on the performance of cellular manufacturing systems. PhD thesis, Washington University.

Hyer, N. L., 1984, The potential of group technology for US manulacturing. Journal of Operation Management, 4(3), 183-201.

Hyer, N. L. and Whmmierlov, U., 1984, Group technology and productivity. Harvard Business Review, July/August.

Hsu, C. P., 1990, Similarity coeflicient approaches to machine-component cell formation in cellular manufacturing: a comparative study. PhD. thesis, Department of Industrial and Systems Engineering, University of Wisconsin-Milwaukee.

KING, J. R., 1980, Machine-component grouping in production flow analysis: an approach using a rank order clustering algorithm. International Journal of Production Research, 18 , $213-237$.

Kumar, C. S. and Chandrasek.haran, M. P., 1990, Grouping efficacy: a quantitative orientation for goodness of block diagonal forms of binary matrices in group technology. International Journal of Production Research, 28(2), 233243.

LAw, A. M. and Kfl IoN, W. D., 1991, Simulation Modeling and Analysis (New York: McGrawHill).

MCCormick, W. T., Schweit/er, P. J. and White, T. W., 1972, Problem decomposition and data rcorganization by a clustering technique. Operations Research, 52, 993- 1009.

Pegiden, C. D., Silanon, R. E. and Sadowski, R. P., 1990, Introduction to Simulation Using SIMIAN (State College, PA: System Modeling Corporation), pp. 9--10.

SARPER, H., 1988, Cellular and functional production environment: design methodology and comparison. $\mathrm{PhD}$ thesis, VPI University.

SASSANI, F., 1990, A simulation study on performance improvement of group technology cells. International Journal of Production Research, 28(2), 293-300. 
Stifoddini, H., 1989, Duplication process in machine cell formation in group technology. Transactions of the Institute of Industrial Engineers (IIE) 21(4), $382-388$.

SEIroddin, H., 1992, Performance evaluation of hybrid cells in cellular manulacturing. Transactions of the Institute of Industrial Engineering (IIE) 24(1), 84-88.

SEIFounINi, H. and Diassemi, M., 1994, Analysis of efficiency measures for block diagonal machine-component charts. Proceedings of the $16 \mathrm{th}$ Intemational Conference on Computers and Inchustrial Engineering, Ashikaga, Japan.

SeIroddin, H. and Wol. F, P., 1986, Application of the similarity coefficient method in group technology. IIE Transactions, 18(3), 271 277.

Shafer, S. and Mertidith, J., 1990, A comparison of selected manufacturing cell formation techniques. International Journal of Production Research, 28(4), 661-673.

W EMmerlov, U. and Hyer, N., 1989, Cellular manufacturing in US industry: a survey of users. International Journal of Production Research 21(9), 15।1 1530. 